\title{
Green Tax Policy, Environmental Decentralization and Energy Consumption: Evidence from China
}

\author{
Xiuyue Deng ${ }^{*}$, Hao Huang2 \\ ${ }^{1}$ School of Computer, Shenyang Aerospace University, Shenyang, China \\ ${ }^{2}$ School of Economics, Yunnan University of Finance and Economics, Kunming, China \\ Email: *dengxiuyue@foxmail.com
}

How to cite this paper: Deng, X. Y., \& Huang, H. (2020). Green Tax Policy, Environmental Decentralization and Energy Consumption: Evidence from China. Modern Economy, 11, 1528-1543.

https://doi.org/10.4236/me.2020.119109

Received: August 4, 2020

Accepted: September 18, 2020

Published: September 21, 2020

Copyright (๑) 2020 by author(s) and Scientific Research Publishing Inc. This work is licensed under the Creative Commons Attribution International License (CC BY 4.0).

http://creativecommons.org/licenses/by/4.0/ (c) (i) Open Access

\begin{abstract}
China's huge energy consumption has caused a series of environmental problems, and taxation is an effective way of regulating energy use. Green tax policy can be divided into narrow sense and broad sense according to its circumscription. Studying the impact of different ranges of green taxation policies on energy consumption is of great significance for improving taxation policies to reduce energy consumption. Based on the government's responsibility for policy implementation and supervision, it is necessary to introduce local government environmental decentralization to explore the role of government actions in it. Taking the panel data of 30 provinces (cities, districts) in China from 2007 to 2016 as the research sample, using the system GMM model, empirically analyze the impact of broad and narrow green taxation and government environmental decentralization on energy consumption and energy efficiency, the results shows: 1 ) The narrow green tax policy can significantly reduce energy consumption and promote energy efficiency. 2) Broad green taxation policy can significantly increase energy consumption and reduce energy efficiency. 3) Whether under the broad or narrow green taxation policy, the increase in environmental decentralization of local governments will significantly reduce the amount of energy consumption and improve energy efficiency.
\end{abstract}

\section{Keywords}

Environmental Pollution, Energy Consumption, Energy Efficiency, Green Tax

\section{Introduction}

There is a very close relationship between energy and environment. Some tradi- 
tional energy sources, such as coal, new materials, straw and so on, produce a lot of harmful gases and greenhouse gases, which bring about environmental problems such as haze, acid rain and greenhouse effect, causing greatly threaten the living environment of human beings and seriously affect the sustainable development of economic society (WHO, 2015). Since 2011, China has become the world's largest energy consumer. From 1978 to 2018, China's total energy consumption has increased by 7.7 times (IEA, 2018). With the rapid growth of energy consumption, some profound problems such as huge energy consumption, imbalance energy consumption structure and low energy efficiency have gradually emerged (Yang \& Sun, 2019; Li \& Huo, 2010; Zhang \& Jiao, 2018; Jiang \& Gao, 2013), resulting in energy waste and environmental pollution, which urgently need to be solved. In order to deal with a series of problems brought about by energy consumption, the Chinese government began to strengthen the management of energy and environment. From the first environmental protection conference in China in the 1970s, to the "Interim Measures for the Collection of Pollutant Discharge Fees" in 1982, the White Paper on China's Energy Policy in 2012, and the strategic thinking of "Energy Revolution" proposed in 2017. In order to achieve safe, stable, economical, and clean energy development, the government constantly issued Intervention policies to encourage using clean energy, improve energy utilization efficiency and reduce pollution emissions.

Among these policies, green tax, as one of many policy means of environmental regulation, is the general term of various green taxes levied by the state to achieve the purpose of energy conservation and environmental protection. From the perspective of the economic role of green tax policy, its core purpose is to achieve economic and ecological environmental benefits. Through intervention in resource allocation, it affects the energy types and utilization methods of the production process, and affects the environmental quality through the final aggregated pollutant discharge (Niu, 2016). Considering that China is in the process of urbanization and industrialization, energy consumption is still growing. With the lack of resources and the increasing demand for energy consumption, it is necessary to implement more accurate and reasonable green tax policies to build an energy-saving and efficient energy system for resource conservation and environmental protection. On the one hand, energy conservation and efficiency need to control the amount of energy consumption, on the other hand, it needs to improve the level of energy utilization. Accurately measuring the extent and direction of green taxation on energy consumption and energy efficiency is a prerequisite for implementing a reasonable and effective green taxation policy.

According to the scope of green tax, it can be divided into two kinds: narrow sense and broad sense. The narrow sense green tax refers to the tax directly levied for environmental protection, while the broad sense green tax policy includes various taxes that directly and indirectly play the role of environmental protection (Fu \& Wang, 2018; Xu \& Zhang, 2018). In terms of the effect of these two tax policies on China's economic growth, there are differences between the 
narrow sense green tax and the broad sense green tax (An \& Li, 2017; Wang \& $\mathrm{Li}, 2018$ ). As far as the effect on the environment is concerned, both the narrow sense and the broad sense green tax policies have a significant inhibitory effect on China's carbon emissions (Fu \& Wang, 2018). Based on the narrow and broad green tax policies covering different taxes and affecting energy consumption from different ways, it is necessary to distinguish green tax policies and measure the impact of narrow green tax and broad green tax on energy consumption respectively.

China's environmental governance has the decentralization of power between the central and local governments. Generally, the central government is responsible for the unified formulation of environmental policies and environmental standards. Local governments mainly ensure the implementation and supervision of relevant environmental policies and regulations. A small number of local governments have also introduced some local policies. Environmental protection policies and environmental protection responsibilities are reasonably allocated among various levels of government through a cooperative governance model between the central and local governments (Sheng, 2016). Local government decentralization is an important institutional arrangement for the government to implement public governance. From the perspective of the economic benefits of local government decentralization, China's fiscal decentralization and local government competition have played a huge role in promoting China's sustained and rapid economic growth (Zhou, 2014). From the perspective of the ecological benefits of environmental decentralization of local governments, increasing the degree of environmental decentralization can help improve the environmental pollution situation (Lu \& Yang, 2019). In the process of implementing China's sustainable energy development strategy, local governments at all levels are policy executors, regulators and even makers, and they have always played a key role in the implementation of policies. Therefore, when studying the effect of green tax policies on energy consumption, it is necessary to introduce the environmental decentralization of local governments to study whether the behavior of local governments affects the effect of green tax policies on energy consumption.

Based on the above questions, this paper attempts to answer the following questions: Can green tax policy effect energy consumption and energy? What's the difference between the effect of broad and narrow sense green tax policies? Will the local government's behavior have an impact on the intervention of green tax policy on energy consumption? Based on the panel data of 30 provinces (cities and autonomous regions) in China from 2007 to 2016, this paper estimates the intensity of the broad and narrow sense green tax policies among 30 provinces in China, expounds the quantitative and qualitative impact of green tax on energy consumption, and analyzes the role of local government environmental decentralization in it. There are many countries that collect energy tax and environmental tax in the world. This paper aims to provide 
policy recommendations for improving green taxation system and better exerting the positive benefits of green taxation policies on energy consumption in similar region.

\section{Literature Review}

\subsection{Green Tax}

Green taxes, also known as environment taxes, are taxes that are imposed for the purpose of directly or indirectly protecting the environment. According to the International Tax Glossary published by the International Bureau of Fiscal Documentation, it refers to tax deductions for taxpayers who invest in pollution prevention or environmental protection, or taxes collection on the use of polluting industries and pollutants. Since the 1970s, the Organisation for Economic Co-operation and Development (OECD) countries have introduced environmental taxes such as resource taxes, garbage taxes, noise taxes, and water pollution tax, carbon dioxide tax, sulfur tax, etc., and have tried to apply environmental policies of economic means to environmental protection (Wang, 2010). The advantage of green taxation is that it can not only effectively encourage the development of clean energy, but also help enterprises to adopt advanced energy-saving technologies (Zhang \& Smith, 2007). At present, after a series of tax reform, some developed countries have formed a green tax system. Japan has gradually formed an ecological tax system dominated by environmental tax and resource tax, Sweden has formed an environmental tax system dominated by carbon dioxide tax, sulfur dioxide and nitrogen dioxide tax, and Denmark has formed a green tax system dominated by resource tax and environmental tax (Rao \& Liu, 2017). In China, pollution discharge fee, land use tax, urban construction and maintenance tax, resource tax, vehicle purchase tax, urban maintenance and construction tax, urban land use tax and vehicle and ship tax all have similar functions of green tax (Wang \& Li, 2018; Deng \& Wang, 2013).

\subsection{The Impact of Green Tax Policies on the Economy and the Environment}

In terms of the impact of green taxes, many literatures has studied the impact of green tax on economic growth and the environment. In terms of the impact of green tax on economic growth, Lu et al. (2018) believe that China's green tax revenue increase can promote economic growth. However, the role of green tax in economic growth may vary in different time periods and needs to be explored separately from the short-term and long-term perspectives. In the short term, $\mathrm{Li}$ et al. (2018) believe that the environmental protection tax levy in Jiangsu Province has increased the burden on enterprises and has a slight inhibitory effect on economic growth in the short term. In the long run, An \& Li (2017) believe that the increase in GDP will positively promote green tax, while green tax has little 
effect on GDP. The narrow sense green tax and the broad sense green tax also have different effects on economic growth. Wang \& Li (2018) divided the green tax policy into narrow and broad senses, and found that both narrow and broad green taxes have an inhibitory effect on the quantity of economic growth, while narrow and broad green taxes respectively promote and suppress the quality of economic growth. In terms of the impact of green taxes on the environment: the collection of environmental taxes plays a crucial role in the dynamics of greenhouse gases (Sapna \& Nivedita, 2019). Sarah \& Gren (2015) and Murray \& Rivers (2015) assessed Swedish environmental taxes on meat and dairy consumption and carbon taxes in British Columbia in western Canada. The environmental impact of the collection of environmental consumption tax and carbon tax can reduce greenhouse gas emissions. The impact of the narrow sense green tax policy on carbon emissions is consistent with the broad sense green tax policy. Based on the distinction between the narrow sense and the broad sense of green tax, the empirical results of carbon emission effects of green tax policies in 30 provinces (cities and autonomous regions) in China show that both the narrow sense and the broad sense of green tax policies have significant inhibition on China's carbon emissions (Fusha et al., 2018). In terms of environmental and economic aspects, some studies believed that green tax can bring both economic and environmental dividends. Andrei et al. (2016) studied the impact of Romania's environmental tax on the development of green economy, and believed that environmental tax can promote economic growth and promote environmental friendliness, representing a path to sustainable development. However, Some studies hold different opinions, they considered that whether the green tax collection can bring economic dividends remains to be discussed. The results of an empirical analysis based on the "double dividend" effect of Zhuhai's environmental protection tax (Chen, 2018) and the full review of all the literature on the dual dividend hypothesis using the CGE model to test environmental tax reform are the same (Freire-González, 2017), That is, the environmental protection tax can indeed improve the environmental quality, but the economic dividend of environmental tax is still a vague problem that remains discussion. In terms of the impact of green tax on energy, taking China's heavy industry as an example, energy structure optimization and technological progress caused by carbon tax collection in the short term can promote energy efficiency. In the long run, the carbon tax can improve energy efficiency in ways that promotes structural changes within the industry and increases industry concentration (Chen, 2017).

\subsection{Energy Consumption}

For the study of energy consumption, the existing literature can be viewed from two aspects: energy consumption and energy efficiency. In the study of energy consumption, there is a widespread view that the level of economic development, urbanization, industrial structure, energy structure, scale of foreign in- 
vestment and technological progress and other factors have a strong correlation with energy consumption (Zeng \& Li, 2014; Liu \& Sun, 2019; Jiang \& Shen, 2016; Wang et al., 2016). In addition, Zhang (2013) compared the impact of GDP, population and industrial structure of China, Japan and South Korea on energy consumption. Su \& Yang (2016) studied the impact of national income, energy prices, the proportion of added value of the secondary industry and the total population on China's total energy consumption. Sun et al. (2019) used LMDI method to study the impact of population effect, per capita GDP, industrial structure, energy intensity and energy structure on urban energy consumption. On the research of energy efficiency, the existing literature has measured China's energy efficiency and its influencing factors from the provincial, municipal and industrial levels respectively. At the provincial level, Li et al. (2019), Chen (2017) and Liu et al. (2018) calculated China's provincial energy efficiency through dynamic SBM model, DEA Malmquist model and DEA BCC model respectively, and analyzed the regional differences and dynamic change characteristics of energy efficiency. At the city level, Liu \& Tian (2019) and Tong \& Chen (2019) respectively studied the energy efficiency of more than 280 cities in China based on dea-sbm model and DEA-Malmquist index, and studied the impact of opening-up level, government policy intervention and human capital on energy efficiency. Yan et al. (2018) focused on the regional differences in energy efficiency of 113 resource-based cities in China. At the industry level, Zhang \& Xu (2018) measured the energy efficiency of each enterprise and its industry based on the data of 136 key energy using enterprises in Guangzhou, China from 2012 to 2015. Chen (2014) studied the impact of ownership structure of manufacturing industry, enterprise energy managers and energy dependence on energy efficiency.

As mentioned above, the previous literature mainly focused on the impact of green tax on economic growth and the environment, and rarely analyzed green tax policy as factors influencing total energy consumption and energy efficiency. Meanwhile, the effect of narrow sense green tax policy and generalized green tax policy on energy consumption is also lack of comparative evaluation. Thus, this study is expected to full this gap in the literature. This paper takes 2007-2016 China provincial data as the sample, on the basis of distinguishing the broad and narrow green taxes, it deeply explores the long-term comprehensive impact of the narrow and broad green tax policies on the quantity and quality of energy consumption by the System GMM model. Moreover, the decentralization of local government environment is taken into account to explore the role of local governments in this process.

\section{Methods}

\subsection{Model Construction}

The model refers to Barla \& Perelman (2005) and Wang \& Li (2018), which has been adjusted according to China's actual situation, to examine the impact of 
green tax policies ( $\operatorname{lnCT}$ ) on the energy consumption (lnEN), energy efficiency (lnEQ). In order to explore whether local government actions will interfere with the impact of green tax policies on energy consumption, therefore, the local government environmental decentralization (lnED) was introduced. The specific model is as follows:

$$
\begin{aligned}
& \operatorname{lnEN}_{i t}=\alpha_{0}+\alpha_{1} \operatorname{lnEN}_{i, t-1}+\alpha_{2} \operatorname{lnCT}_{i t}+\alpha_{3} \operatorname{lnED}_{i t}+X_{i t} \lambda+\varepsilon_{i t} \\
& \operatorname{lnEQ_{it}}=\beta_{0}+\beta_{1} \operatorname{lnEQ}_{i, t-1}+\beta_{2} \operatorname{lnCT}_{i t}+\beta_{3} \operatorname{lnED}_{i t}+X_{i t} \lambda+\eta_{i t}
\end{aligned}
$$

$\alpha_{0}$ and $\beta_{0}$ are intercept terms; $\alpha_{i}$ and $\beta_{i}$ are regression coefficients; $\varepsilon_{i t}$ and $\eta_{i t}$ are error terms. $X$ represents control variables.

\subsection{Variables}

\subsubsection{Interpreted Variables}

Energy consumption (EN): is measured by converting the annual main energy consumption into the standard coal quantity according to the current national standard of various energy conversion standard coal reference coefficient in China, and the unit is 10,000 tons of standard coal.

Energy efficiency (EQ): Refer to the method of Li \& Zheng (2019), the model is:

$$
\begin{gathered}
\ln Y_{i t}=\beta_{0}+\beta_{1} \ln K_{i t}+\beta_{2} \ln L_{i t}+\beta_{3} \ln E_{i t}+v_{i t}-u_{i t} \\
\mathrm{EQ}_{i t}=\frac{E\left[f\left(x_{i t}\right) \exp \left(v_{i t}-u_{i t}\right)\right]}{E\left[f\left(x_{i t}\right) \exp \left(v_{i t}\right) \mid u_{i t}=0\right]}=\exp \left(-u_{i t}\right)
\end{gathered}
$$

$i$ and $t$ respectively represent the region and year; $Y$ represents output, measured by regional GDP; $K$ represents capital, measured by capital stock, According to the perpetual inventory method of Zhang et al. (2004), the calculation formula is: $K_{i t}=I_{i t}+\left(1-\delta_{i t}\right) K_{i t-1}, I$ represents the actual total fixed capital formation with 2000 as the base period. The depreciation rate $\delta$ is 9.6\%; $L$ represents labor, measured by the number of employed persons; $E$ represents energy input, measured by the total annual energy consumption of each province. $v_{i t}-u_{i t}$ Constitute compound error, $v_{i t} \sim \operatorname{iidN}\left(0, \sigma_{v}^{2}\right)$, which represents external influencing factors and statistical errors; and independent with $U_{i t} ; U_{i t}$ is a nonnegative random variable $u_{i t} \sim \operatorname{iidN}\left(0, \sigma_{u}^{2}\right)$, assuming it can explain the technical inefficiency in production. On this basis, the energy efficiency $E Q_{i t}=\exp \left(-u_{i t}\right)$ can be calculated.

According to Battese \& Coeli (1992), the significance test of $\gamma$ is used to analyze whether the phenomenon of technical inefficiency occurs.

$$
\gamma=\frac{\sigma_{u}^{2}}{\sigma_{u}^{2}+\sigma_{v}^{2}}
$$

$\gamma$ is the parameter to be estimated, $\gamma \in(0,1)$. When $\gamma$ is close to 1 , it indicates that the difference is mainly caused by technical inefficiency. At this time, the SFA method is most suitable (Xu \& Yang, 2012). The SFA estimation results are shown in Table 1. 
Table 1. SFA estimation results.

\begin{tabular}{cccc}
\hline Variables & Coefficient & Standard-error & t-ratio \\
\hline beta 0 & -0.6065 & 0.7469 & -0.8120 \\
beta 1 & 0.8715 & 0.1066 & 8.1789 \\
beta 2 & -0.0520 & 0.0941 & -0.5533 \\
beta 3 & 0.3556 & 0.0669 & 5.3113 \\
gamma & 0.9412 & 0.0077 & 122.9535 \\
\hline T test & 310.8660 & & \\
LR test & 667.0755 & & \\
\hline
\end{tabular}

Note: The results were sorted out according to FRONTIER4.1, with four decimal places reserved.

The $\gamma$ value in this paper is 0.9412 , and it has significantly passed the $t$ test and the likelihood ratio test. Therefore, the SFA model can be used to calculate energy efficiency.

\subsubsection{Core Interpretation Variables}

Green Tax Policy (CT): The green tax policy is divided into two perspectives: narrow sense green tax policy intensity (CT1) and broad sense green tax policy intensity (CT2). China's environmental protection tax law came into force on January 1, 2018. Therefore, before this, due to the environmental protection tax with this feature has not yet been levied, the pollution discharge fee with the function of environmental protection tax will be used as an alternative indicator of the narrow green tax policy. China's current tax reform also supports this alternative measure (Wang \& $\mathrm{Li}, 2018$ ). The pollution discharge fee are used as a substitute for the narrow green tax policy. Therefore, the narrow sense green tax policy intensity $=$ pollution discharge fee/(total revenue + pollution discharge fee). The method of measuring the intensity of generalized green tax refers to Deng \& Wang (2013), that is, the generalized green tax policy intensity $=(7$ green tax revenue + pollution discharge fee)/(total revenue + pollutant discharge fee), taxes related to green taxes include seven types of taxes, includingresource tax, cultivated land occupation tax, urban maintenance and construction tax, consumption tax, vehicle purchase tax, vehicle and vessel tax, urban land use tax.

Environmental decentralization (ED): Measured using the number of people in the environmental protection system of local governments in different regions. The specific calculation formula is:

$$
\mathrm{ED}=\left[\left(\mathrm{NAEPP}_{i t} / \mathrm{pop}_{i t}\right) /\left(\mathrm{NEPP}_{t} / \mathrm{pop}_{t}\right)\right] \times\left[1-\left(\mathrm{GDP}_{i t} / \mathrm{GDP}_{t}\right)\right]
$$

NAEPP and NEPP respectively represent the number of environmental protection practitioners in the region and the country, and POP represents the local population. 


\subsubsection{Control Variables}

According to the previous research (Liu \& Tian, 2019; Fu, 2017; Tong \& Chen, 2019), the control variables are selected as follows:

Economic development level (pgdp): Measured by per capita gross regional product, the unit is ten thousand yuan.

Urbanization (urban): Measured by the proportion of urban population in the permanent population of the area at the end of the year.

Industrial structure adjustment (is): Measured by the ratio of the added value of the tertiary industry to that of the secondary industry.

Foreign investment (fdi): Measured by the proportion of foreign direct investment in each region to the regional GDP.

Dependence on foreign trade (open): Measured by the proportion of the total import and export of goods in the region to the region's GDP.

Technological innovation (ch): Measured by the number of technological patents granted.

Resource endowment $(\mathrm{kl})$ : Measured by the ratio of regional capital stock and labor force.

In order to avoid autocorrelation and heteroscedasticity, and to make the regression coefficients represent elasticity and have more economic significance, the variables are logarithmized. The maximum, minimum, average and quantity of all variables are shown in Table 2. Mostvariable is basically between -10 and 10 , and it will not affect the whole index system due to a certain variable being too large or small.

Table 2. Descriptive statistics.

\begin{tabular}{|c|c|c|c|c|}
\hline variable & average & Minimum & Maximum & count \\
\hline $\operatorname{lnEN}$ & 9.303 & 6.963 & 10.569 & 300 \\
\hline $\ln E Q$ & -1.160 & -1.989 & -0.643 & 300 \\
\hline $\operatorname{lnCT} 1$ & -6.175 & -10.403 & -3.707 & 300 \\
\hline $\operatorname{lnCT} 2$ & -1.693 & -3.174 & -0.964 & 300 \\
\hline $\operatorname{lnED}$ & 0.046 & -0.643 & 1.088 & 300 \\
\hline lnpgdp & 10.469 & 8.972 & 11.680 & 300 \\
\hline lnurban & -0.654 & -1.264 & -0.110 & 300 \\
\hline $\operatorname{lnis}$ & -0.099 & -0.699 & 1.427 & 300 \\
\hline $\operatorname{lnfdi}$ & -4.095 & -7.860 & -2.502 & 300 \\
\hline lnopen & -1.693 & -3.437 & 0.579 & 300 \\
\hline Lnch & 9.334 & 5.403 & 12.506 & 300 \\
\hline $\operatorname{lnkl}$ & 2.415 & 1.040 & 3.885 & 300 \\
\hline
\end{tabular}




\subsection{Data Source}

This paper uses the panel data of 30 provinces (cities, autonomous regions) in China from 2007 to 2016. The sources of research data include China Statistical Yearbook, China Tax Yearbook, China Environmental Yearbook and China Energy Statistics Yearbook, statistical yearbook of each province, and relevant database. The data of Hong Kong, Macao and Taiwan are not available, and the data of Tibet are discontinuous, thus, the data does not involve Hong Kong, Macau, Taiwan and Tibet.

\section{Results Analysis}

This article takes the energy consumption situation in the context of China's green tax policy as an entry point. Based on the panel data of 30 provinces (cities, autonomous regions) in China from 2007 to 2016, we discuss the impact of broad green taxation on energy consumption and energy efficiency from narrow sense and broad sense, and explore the role of local government's environmental decentralization in this process. Taking into account the possible endogenous problems of panel data characteristics and explanatory variables, this paper adopts the system generalized moment estimation (SYS-GMM) method for model estimation. The regression results and GMM test results are shown in Table 3. The regression results of the narrow green tax (lnCTI1) and the general green tax (lnCTI2) on energy consumption (lnEN) are shown in column (1) and (2) in Table 3, and the regression results on energy efficiency ( $\operatorname{lnEQ}$ ) are shown in Table 3. (3) (4) column.

From the regression results in Table 3 , it can be seen that energy consumption and energy efficiency have a significant lag. From the columns (1) and (2) of Table 3, we can see that the coefficient of the narrow green tax (lnCTI1) on energy consumption is negative, but it is not statistically significant; the general green tax (lnCTI2) will significantly increase Energy consumption (lnEN). Regardless of whether in the narrow or broad sense of green taxation policies, the local government environmental decentralization $(\operatorname{lnED})$ will significantly reduce energy consumption (lnEN). In the narrow defined green taxation (lnCTI1), every $1 \%$ increase in local government environmental decentralization $(\operatorname{lnED})$ will reduce energy consumption ( $\operatorname{lnEN}$ ) by about $0.13 \%$. Under the broad sense green taxation policy (lnCTI2), for every $1 \%$ increase in local government environmental decentralization (lnED), energy consumption (lnEN) will correspondingly decrease by about $0.11 \%$.

In Table 3 (3) (4), the narrow sense green taxation (lnCTI1) can significantly improve energy efficiency. For every $1 \%$ increase in the intensity of the narrow green taxation (lnCTI1), the energy efficiency will increase by $0.28 \%$; the generalized green taxation (lnCTI2) will significantly reduce energy efficiency. (LnEQ). The local government environmental decentralization (lnED) has no significant impact on energy efficiency ( $\mathrm{LnEQ}$ ) under the narrow sense green taxation policy, while under the broad sense of green taxation, environmental decentralization $(\operatorname{lnED})$ will improve energy efficiency (LnEQ). For every $1 \%$ increase in 
Table 3. Estimation results of the impact of green taxes on energy consumption and energy efficiency.

\begin{tabular}{|c|c|c|c|c|}
\hline variables & $\begin{array}{c}(1) \\
\operatorname{lnEN}\end{array}$ & $\begin{array}{c}(2) \\
\operatorname{lnEN}\end{array}$ & $\begin{array}{c}(3) \\
\ln E Q\end{array}$ & $\begin{array}{c}(4) \\
\ln E Q\end{array}$ \\
\hline L.lnEN & $\begin{array}{l}0.757^{\star * *} \\
{[0.0319]}\end{array}$ & $\begin{array}{l}0.775^{\star * *} \\
{[0.0246]}\end{array}$ & & \\
\hline L.lnEQ & & & $\begin{array}{l}0.206^{* * *} \\
{[0.0292]}\end{array}$ & $\begin{array}{l}0.220^{* * *} \\
{[0.0202]}\end{array}$ \\
\hline $\operatorname{lnCTI1}$ & $\begin{array}{c}-0.00366 \\
{[0.0088]}\end{array}$ & & $\begin{array}{l}0.281^{\star * *} \\
{[0.0337]}\end{array}$ & \\
\hline $\operatorname{lnCTI} 2$ & & $\begin{array}{c}0.0480^{* * *} \\
{[0.0073]}\end{array}$ & & $\begin{array}{c}-0.0948^{\star * *} \\
{[0.0316]}\end{array}$ \\
\hline $\ln E D$ & $\begin{array}{c}-0.133^{* * *} \\
{[0.0352]}\end{array}$ & $\begin{array}{c}-0.115^{* * *} \\
{[0.0317]}\end{array}$ & $\begin{array}{c}0.507 \\
{[0.4351]}\end{array}$ & $\begin{array}{l}0.495^{\star * \star} \\
{[0.1013]}\end{array}$ \\
\hline lnpgdp & $\begin{array}{l}0.00319 \\
{[0.0031]}\end{array}$ & $\begin{array}{c}0.00285 \\
{[0.0030]}\end{array}$ & $\begin{array}{c}0.0465^{* * *} \\
{[0.0098]}\end{array}$ & $\begin{array}{c}0.0586^{\star * *} \\
{[0.0068]}\end{array}$ \\
\hline $\operatorname{lnis}$ & $\begin{array}{c}-0.179^{\star * *} \\
{[0.0183]}\end{array}$ & $\begin{array}{c}-0.155^{* * *} \\
{[0.0178]}\end{array}$ & $\begin{array}{c}-0.363^{\star * *} \\
{[0.0682]}\end{array}$ & $\begin{array}{c}-0.347^{\star * *} \\
{[0.0899]}\end{array}$ \\
\hline lnurban & $\begin{array}{l}0.666^{\star * *} \\
{[0.0967]}\end{array}$ & $\begin{array}{l}0.733^{\star * *} \\
{[0.0857]}\end{array}$ & $\begin{array}{c}-3.427^{* * *} \\
{[0.8916]}\end{array}$ & $\begin{array}{c}-4.379^{\star * *} \\
{[1.0168]}\end{array}$ \\
\hline $\operatorname{lnfdi}$ & $\begin{array}{c}-0.00857^{\star} \\
{[0.0050]}\end{array}$ & $\begin{array}{c}-0.0113^{* *} \\
{[0.0051]}\end{array}$ & $\begin{array}{c}0.140^{\star *} \\
{[0.0545]}\end{array}$ & $\begin{array}{l}0.139^{\star * \star} \\
{[0.0503]}\end{array}$ \\
\hline lnopen & $\begin{array}{c}-0.0115^{\star *} \\
{[0.0048]}\end{array}$ & $\begin{array}{c}0.0103^{\star} \\
{[0.0061]}\end{array}$ & $\begin{array}{l}0.431^{\star * *} \\
{[0.0485]}\end{array}$ & $\begin{array}{l}0.286^{\star * *} \\
{[0.0400]}\end{array}$ \\
\hline $\operatorname{lnch}$ & $\begin{array}{c}0.0422^{* * *} \\
{[0.0081]}\end{array}$ & $\begin{array}{c}0.0311^{\star * \star} \\
{[0.0064]}\end{array}$ & $\begin{array}{c}-0.135^{\star * *} \\
{[0.0464]}\end{array}$ & $\begin{array}{c}-0.214^{\star * *} \\
{[0.0329]}\end{array}$ \\
\hline $\operatorname{lnkl}$ & $\begin{array}{c}-0.127^{\star * *} \\
{[0.0169]}\end{array}$ & $\begin{array}{c}-0.133^{* * *} \\
{[0.0152]}\end{array}$ & $\begin{array}{l}1.143^{\star * *} \\
{[0.2017]}\end{array}$ & $\begin{array}{l}1.229^{\star * *} \\
{[0.2145]}\end{array}$ \\
\hline _cons & $\begin{array}{l}2.518^{\star * *} \\
{[0.3299]}\end{array}$ & $\begin{array}{l}2.645^{\star * *} \\
{[0.2355]}\end{array}$ & $\begin{array}{c}-2.161^{\star *} \\
{[0.9121]}\end{array}$ & $\begin{array}{c}-4.517^{\star * *} \\
{[1.1389]}\end{array}$ \\
\hline $\mathrm{AR}(1)$ & $\mathrm{P}=0.0006$ & $\mathrm{P}=0.0003$ & $\mathrm{P}=0.0000$ & $\mathrm{P}=0.0000$ \\
\hline $\mathrm{AR}(2)$ & $\mathrm{P}=0.5134$ & $\mathrm{P}=0.6704$ & $\mathrm{P}=0.2756$ & $\mathrm{P}=0.3335$ \\
\hline sargan & $P=0.9765$ & $\mathrm{P}=0.9774$ & $\mathrm{P}=0.4549$ & $\mathrm{P}=0.4013$ \\
\hline Observations & 270 & 270 & 270 & 270 \\
\hline Number of id & 30 & 30 & 30 & 30 \\
\hline
\end{tabular}

Note: The standard brackets in the table are standard errors, the square brackets are p-values; ${ }^{*}{ }^{* *}$, and ${ }^{* * *}$ indicate significant levels of significance at $10 \%, 5 \%$, and $1 \%$. 
local government environmental decentralization $(\operatorname{lnED})$, energy efficiency (LnEQ) will increase by about $0.49 \%$.

In terms of control variables, the empirical results prove that the improvement of economic development (lngdp) will promote the improvement of energy efficiency, which is also in line with general expectations, because the increase of GDP per capita often means a richer life and more advanced production methods (Lin, 2012). In terms of energy selection, it is possible to choose energy types with higher efficiency and less pollution, and to choose more efficient production methods in energy use. The upgrading of the industrial structure (lnis) will reduce energy consumption, which proves that the increase of the tertiary industry can indeed reduce energy consumption compared to the secondary industry where the industry is concentrated. The advancement of urbanization (lnurban) will promote an increase in energy consumption, because in the process of urbanization, the gradual accumulation of population will bring about greater energy consumption. The increase in foreign direct investment (lnfdi) will reduce energy consumption and improve energy efficiency. This can be explained by the increase in foreign investment means a large amount of foreign capital. These funds may expand the choice of energy types used by enterprises and increase investment in technology research and development to promote energy structure adjustment and stimulate energy efficiency improvement. The degree of dependence on foreign trade (lnopen) can significantly improve energy efficiency under both tax policies. This can be explained as an increase in import and export trade, which may introduce more advanced production and management methods, and improve energy efficiency by shortening product production processes. Meanwhile, the increase in resource endowment (kl) can also significantly reduce energy consumption and improve energy efficiency.

\section{Conclusion and Recommendations}

\subsection{Research Conclusion}

This paper uses panel data from 30 provinces (municipalities and autonomous regions) in China from 2007 to 2016 to establish a systematic GMM model. Based on the introduction of local government environmental decentralization, this paper conducts an empirical analysis of the impact of broad and narrow green taxes on energy consumption. The study found that: 1) Narrow sense green taxation policy can significantly reduce energy consumption and improve energy efficiency, which shows that taxation policies that directly affect pollution results can play a very positive role in my country's energy consumption. 2) Broad sense green taxation policies can significantly increase energy consumption and reduce energy efficiency. This can be explained by the fact that under the current generalized green tax intensity, the cost burden of enterprises has increased, but they have not chosen to replace efficient production tools or means of production to reduce pollution emissions. Instead, they chose to reduce input costs, such as using cheap and inefficient energy to maintain profitability, which led to 
a decline in energy efficiency. 3) Increased environmental decentralization of local governments will significantly reduce energy consumption and improve energy efficiency, which shows that the work of local environmental protection system personnel has indeed reduced the energy consumption of people in the region and has a positive impact on energy efficiency.

\subsection{Policy Recommendations}

Based on the above conclusions, the current green tax system can continue to be optimized in the following aspects: first, we must pay attention to the narrow green tax policy; second, we need to improve the environmental decentralization of local governments. Therefore, the following policy recommendations are put forward: 1) Continue to implement the narrow sense green taxation policy. Directly impose taxes on pollution and waste emissions can generate direct behavioral incentives for manufacturers and promote the efficiency improvement of the company's unit production capacity. In addition, it is also possible to adopt policies such as tax reduction or exemption for companies that use clean energy or companies with higher unit production capacity to solve the problem of environmental pollution from the source. 2) Establish a supervision mechanism to ensure the effective implementation of green tax policies. There are information asymmetry problems in the implementation of the green tax policy. For example, in some areas, there are loopholes in the declaration of environmental protection tax by taxpayers, which is easy to cause "moral hazard", which will affect the implementation of the policy to a certain extent effect. Local governments need to design reasonable supervision mechanisms to ensure that green taxes restrict energy consumption effectively. 3) Appropriately increase the environmental decentralization of local governments. Due to differences in resource endowments and energy consumption characteristics in different regions, a unified policy may not achieve the best results. Local governments need to be given greater authority and more environmental protection personnel to suit one's methods to the situation, and practically solve various problems caused by unreasonable regional energy consumption.

\subsection{Contribution and Deficiency of the Paper}

The main contribution of this paper lies in the combination of green tax policy, environmental decentralization and energy consumption, which further enriches the theory of energy economics and environmental economics. According to the empirical results, it puts forward policy suggestions on how to optimize the green tax system and how to adjust the local government to improve energy efficiency. The deficiency is that the selected literature is limited and the theory is not mature enough. Due to the limitation of data, the research is in the initial stage, the method used is relatively simple and it can be further expanded in the future.

\section{Conflicts of Interest}

The authors declare no conflicts of interest regarding the publication of this paper. 


\section{References}

An, F. R., \& Li, M. (2017). Research on the Relationship between China's Green Taxation and Economic Growth. Journal of Dongbei University of Finance and Economics, No. 5, 65-70.

Andrei, J., Mieila, M., Popescu, G. et al. (2016). The Impact and Determinants of Environmental Taxation on Economic Growth Communities in Romania. Energies, 9, 902. https://doi.org/10.3390/en9110902

Barla, P., \& Perelman, S. (2005). Sulphur Emissions and Productivity Growth in Industrialised Countries. Annals of Public Cooperative Economics, 76, 275-300. https://doi.org/10.1111/j.1370-4788.2005.00279.x

Battese, G. E., \& Coeli, T. J. (1992). Frontier Production Functions, Technical Efficiency and Panel Data: With Application to Paddy Farmer in India. Journal of Productivity Analysis, 3, 153-169. https://doi.org/10.1007/BF00158774

Chen, A. Z. (2018). Analysis on the Double Dividend Effect of Environmental Protection Tax in Zhuhai City. Taxation, 12, 11-12.

Chen, G. J. (2014). Research on the Total Factor Energy Efficiency and Influencing Factors of China's Manufacturing Industry: Stochastic Frontier Analysis Based on Panel Data. China Soft Science, No. 1, 180-192.

Chen, H. Y. (2017). Analysis of China's Regional Energy Efficiency and Its Influencing Factors-Based on the DEA-Malmquist Model. Journal of Guizhou University of Finance and Economics, No. 6, 32-39.

Chen, M. S. (2017). Research on the Mechanism of Carbon Tax Collection to Improve Energy Efficiency. Journal of China University of Political Science and Law, No. 5, $112-122+160$.

Deng, X. L., \& Wang, Y. J. (2013). Research on the Greening Degree of China's Taxation System-Based on the Measurement of Three Statistical Indicators of Large, Medium and Small. Auditing and Economic Research, 28, 71-79.

Freire-González, J. (2017). Environmental Taxation and the Double Dividend Hypothesis in CGE Modelling Literature: A Critical Review. Journal of Policy Modeling, 40, 194-223.

Fu, S., \& Wang, J. (2018). Did Green Tax Policies Reduce China's Carbon Emissions?An Empirical Study Based on the Extended STIRPAT Model. Modern Economic Research, No. 2, 72-78.

Jiang, W., \& Gao, W. D. (2013). Analysis of the Growth Characteristics and Influencing Factors of Energy Consumption in China. World Geographical Research, 22, 160-168.

Jiang, X. L., \& Shen, Z. Y. (2016). The Impact of Industrial Structure on Energy Consumption: Taking Hebei Province as an Example. Southern Economy, No. 3, 54-67.

Li, G. Z., \& Huo, Z. J. (2010). Energy Consumption, Energy Consumption Structure and Economic Growth in China: An Empirical Study Based on ARDL Model. Contemporary Economic Science, 32, 55-60 + 125-126.

Li, H. B., Zhang, B. B., \& Gu, J. Y. (2019). Domestic Market Scale and China's Energy Efficiency Improvement: An Empirical Study Based on the Threshold Effect of Dynamic Panels. China Population Resources and Environment, 29, 61-70.

Li, H. J., Xu, W. W., \& Zhang, Y. (2018). Environmental Protection Tax and Its Impact on Economy: A Case Study of Jiangsu Province. Journal of China Institute of Environmental Management, 6, 1-4.

Li, Y. X., \& Zheng, L. (2019). Research on Economic Growth Efficiency and Influencing Factors of Western Provinces-An Empirical Analysis Based on SFA Model. Ecological 
Economy, 35, 57-62.

Lin, Y. F. (2012). Review and Prospect of China's Economic Development. China's Circulation Economy, 26, 4-8.

Liu, H. M., Zhang, Z. X., \& Wang, L. Y. (2018). Research on China's Provincial Energy Efficiency and Influencing Factors from the Perspective of Supply-Side Reform. Statistics and Decision, 34, 131-136.

Liu, X. R., \& Sun, T. (2019). The Threshold Effect of Financial Development on the Dynamic Economic Growth of China's Energy Consumption. Contemporary Finance and Economics, No. 8, 48-57.

Liu, Y. S., \& Tian, Y. H. (2019). Research on the Impact of My Country's Industrial Structure Adjustment on Energy Efficiency-Based on the Test of Convergence Hypothesis. Hunan Social Sciences, No. 4, 100-107.

Lu, F. Z., \& Yang, H. C. (2019). Environmental Decentralization, Local Government Competition and China's Ecological Environment Pollution. Industrial Economic Research, No. 4, 113-126.

Lu, M., Liu, H. X., \& Liu, J. Y. (2018). An Empirical Analysis of the Impact of My Country's Green Tax Policy on the Economy. Taxation Research, No. 11, 15-19.

Murray, B., \& Rivers, N. (2015). British Columbia’s Revenue-Neutral Carbon Tax: A Review of the Latest "Grand Experiment" in Environmental Policy. Energy Policy, 86, 674-683. https://doi.org/10.1016/j.enpol.2015.08.011

Niu, L. J. (2016). Research on the Impact of Environmental Regulations on Energy Efficiency in the Western Region. Lanzhou: Lanzhou University.

Rao, Y. L., \& Liu, Z. P. (2017). Reference Significance of Green Taxation Practices in Western Countries to My Country's Green Taxation Reform. Economic Forum, No. 7, 147-152.

Sapna, D., \& Nivedita, G. (2019). Effects of Inclusion of Delay in the Imposition of Environmental Tax on the Emission of Greenhouse Gases. Chaos, Solitons \& Fractals, 125, 41-53. https://doi.org/10.1016/j.chaos.2019.05.006

Sarah, S., \& Gren, I. M. (2015). Effects of an Environmental Tax on Meat and Dairy Consumption in Sweden. Food Policy, 55, 41-53.

https://doi.org/10.1016/j.foodpol.2015.05.008

Su, S., \& Yang, T. (2016). Analysis and Prediction of Influencing Factors of Energy Consumption in China-Based on Co-Integration and Error Correction Model. Ecological Economy, 32, 73-76.

Sun, Q., Wang, P., Cai, G. T., Zhao, D. Q., \& Zhong, S. F. (2019). Research on the Evaluation Model of the Total Urban Energy Consumption Index Based on LMDI. Ecological Economy, 35, 98-105.

Tong, J. D., \& Chen, X. (2019). Export Expansion, Environmental Regulation and Energy Efficiency: Empirical Evidence from the Chinese City Level. Exploration of Economic Issues, No. 6, 174-184.

Wang, J., \& Li, P. (2018). The Quantitative and Qualitative Effects of Green Taxation Policies on Economic Growth. China Population, Resources and Environment, 28, 17-26.

Wang, R. (2010). The Enlightenment of OECD National Environmental Taxation Legal System to Our Country's Relevant Legislation. Beijing: Capital University of Economics and Business.

Wang, X. Y., Shen, L., Cheng, J. H., \& Lin, Y. Y. (2016). Cooperative Measurement Analysis of China's Industrial Structure and Energy Consumption Structure. Statistics and Decision, No. 14, 113-117. 
Xu, H. C., \& Zhang, X. J. (2018). Discussion on Perfecting My Country’s Green Taxation System. Taxation Research, No. 9, 101-104.

Xu, J. Q., \& Yang, Y. H. (2012). Analysis of My Country's Provincial Energy Efficiency and Its Influencing Factors-SFA Method Based on Panel Data from 2001 to 2010. Journal of Shanxi University of Finance and Economics, 34, 71-78.

Yan, D., Lei, Y. L., \& Li, L. (2018). Research on Energy Efficiency of Chinese Resource-Based Cities under Environmental Constraints. Journal of Hubei Normal University (Philosophy and Social Sciences Edition), 38, 91-96.

Yang, Y. M., \& Sun, J. D. (2019). Research on the Decoupling and Driving Factors of Carbon Emissions from Energy Consumption in Major Countries. Coal Engineering, 51, 173-177.

Zeng, S., \& Li, R. Q. (2014). Research on the Influencing Factors of Energy Consumption Structure. World Science and Technology Research and Development, 36, 10-14.

Zhang, J. F., \& Smith, K. R. (2007). Household Air Pollution from Coal and Biomass Fuels in China: Measurements, Health Impacts, and Interventions. Environmental Health Perspectives, 115, 848-855. https://doi.org/10.1289/ehp.9479

Zhang, K., \& Jiao, Y. (2018). Looking at the Diversification of My Country's Energy Composition and the Strategic Thinking of Adapting Measures to Local Conditions from the Perspective of Energy Era Replacement and "Gas Shortage". Sino-Foreign Energy, 23, $1-19$.

Zhang, W. X. (2013). Research on the Impact of GDP, Population and Industrial Structure on Energy Consumption in China, Japan and South Korea. China Population Resources and Environment, 23, 125-134.

Zhang, Y., \& Xu, L. D. (2018). An Empirical Study of Micro-Enterprise Energy Efficiency and Influencing Factors Based on SFA. Social Scientist, No. 5, 57-63.

Zhou, Y. A. (2014). Local Government Governance: Decentralization, Competition and Transformation. People's Forum Academic Frontier, No. 4, 14-23. 